\title{
FPS Tour to Rwanda and Zaire
}

\section{Sir Hugh Elliott}

The Society's tour to Rwanda and Zaire, in July, broke new ground both for the Society and for any British wildlife tour. The fifteen members who took part were rewarded by, among other things, a wonderful experience of mountain gorillas at ten-foot range and a ringside view of a live volcano. Sir Hugh was leader of the party.

For a variety of reasons, there seemed to be a good chance of Oryx Tour No. 20 being something of a milestone in the Society's progressive development of conservation-oriented travel. So indeed it proved. Despite the inevitable hitches, discomforts and occasional disappointments of any new venture, none of the sixteen participants are likely to forget or regret it. Its success and our enjoyment depended on a number of factors. We were extraordinarily lucky with the weather, which is just as unpredictable in equatorial Africa as in Britain: rainstorms occurred at convenient times and places in what is allegedly a dry month, keeping the air fresh and the countryside green. We owed a great deal to the skill, patience and kindness of our shepherdess, Patricia Hodgkins of Oxford, and of Kisimba Rubayita (better known as Peter) of Goma, our principal guide, negotiator and source of information. Breakdowns and delays (other than those traditionally associated with airline operations and plumbing) were reasonably few-only one puncture in upwards of a 1000 miles of minibus journeying over mostly dirt-or-pumice mountain roads and tracks must surely be a record. Above all, we managed to achieve our main purpose of getting to know, as well as anyone could do in the time available, a wide range of magnificent landscapes and a satisfying sample of the plants and animals.

Veterans of some previous FPS tours might perhaps regard our bird-list of a mere 240 species as indicating a comparatively impoverished fauna, although it included such choice items as the rufous-bellied heron, Baudouin's harrier-eagle and great sparrow hawk, a gaggle of 37 crowned cranes, a hotel-haunting grey-capped warbler Eminia lepida (one of Africa's top songsters) and the almost comical mix-up of pelicans, marabou and yellow-billed storks (not to mention elephants and hippos) with the fisher-folk of Vitshumbi village. But not only was this a time of year when most of the 150 or more species of migrants from the north are absent, but about half our viewing had to be from minibuses and the other half was in thick montane bush and rain-forest where birds are hardest to see and identify, except perhaps in the first hour after dawn. Alas, we could only be in more or less the right spot at that hour on one of our fifteen dawns, but were shrouded in mist and not quite at our best after a night in a tin hut at $10,000 \mathrm{ft}$ on Nyaragongo volcano.

The 'excursion' to that hut and a thousand feet above it to the rim of the active crater, accomplished by half the party, was of course a highlight in more senses than one. Definitely in the category 
us to a group of four males, two females and five juveniles feeding in a densely foliaged fruiting tree, but for most of us this first encounter consisted of tantalising glimpses of a hairy arm or leg or a couple of beady eyes summing us up over the edge of a broad leaf. There followed at least an hour of trailing hither and thither to possible viewpoints, but still with only distant and fleeting views of the apes till we finally emerged onto the road again. And there was Casimir, the group leader, all $500 \mathrm{lbs}$ of him, sitting in the roadside herbage filling himself up methodically with juicy bark peeled from the long shoots of a shrub. He took little notice of the whirring and clicking cameras less than ten yards away, reassured no doubt by Deschryver's soothing remarks from even closer range, and the unconcerned antics of a gammy-armed female and one or two infants, a little further down the slope. So we too had our fill.

It was in every way a fitting climax to the tour and, when a couple of days later we started our long journey home, our hope was that the knowledge we had gained will help others to share these wonderful sights and sounds for many years to come and that our delight in them will confirm the Rwanda and Zaïre governments in their resolve to conserve their natural treasures. Mr Tatala, the Chief Warden of the Rwindi sector of the Virunga National Park, together with his assistant, J. P. von der Becke, whom he very kindly authorised to take us out one morning on a special non-public circuit which included a chance of stretching our legs and proved immensely enjoyable, met us for an hour one evening to talk about park policy and answer questions - a very kind gesture when they were preparing for a visit to the Park by President Mobutu Sese Soko a couple of days later. He described the policy as 'conservation first and tourism second', which seems to be the right way round, if the results of reversing that order in other parts of the world is any guide.

\section{Alligators in Louisiana}

An experimental alligator harvest programme in Louisiana in 1972 resulted in 61 hunters killing 1350 alligators averaging nearly $7 \mathrm{ft}$ in the 13-day season. The state Wildlife and Fisheries Commission reports that the alligator populations appeared unaffected by the harvest, that there was no indication of any increase in poaching activity, and that there was no evidence of illegal skins entering the legal traffic. However, one of the Commission's own special agents was caught red-handed in June 1973 with the back of his pickup full of freshly salted alligator hides. An equivalent number, 43, were found at his home. No doubt the Commission is now rechecking its information about poaching.

\section{Vicuña Ponchos}

Ponchos made of vicuña wool are advertised in Argentina as 'good examples of Catamarca folk art' in order to attract tourist sales. This despite the fact that vicuña are totally protected in Argentina. The journal Natura reports that it has made representations to the responsible government departments, and that many daily newspapers have drawn attention to the trade in vicuña goods that is going on in Buenos Aires. 